\title{
Early Handling of the Liquor Problem
}

\author{
By M. M. Morris AND E. E. JACK
}

Women played an active part in keeping some sections of Iowa dry in the middle 1800's. In spite of efforts as early as 1859, of both men and women to keep Newton, Iowa, a dry community, after the Civil War period a liquor establishment did set up shop there.

A group of women representing all of the Protestant churches bought black sateen for aprons just large enough to cover a hatchet; and each bought her own hatchet at the hardware store in order to avoid suspicion.

A boxcar from Chicago brought the liquor into Iowa City where the railroad ended. Then it was hauled on into Newton in a covered wagon, drawn by several horses. The cargo arrived at four o'clock, just as the children were coming from school.

After it was all placed ready for business, the black aproned women entered the establishment. Armed with their hatchets, they knocked the containers open, letting the whiskey escape through the store out into the ruts of the dirt road. A few thirsty bystanders dropped to their stomachs and lapped up the juice with their tongues while the helpless bartender looked on.

Undaunted, after a few days, he received reinforcements and fled to a new location in the north Newton woods, where he operated under "a blind pig" (speakeasy fashion).

His period of business was short. The husbands of the Black Apron Hatchet Brigade, prominent business and professional men, under leadership of Constable E. W. Mitchell, chased him out of town. His whereabouts were unknown forever after. 
Copyright of Annals of Iowa is the property of State of Iowa, by \& through the State Historical Society of Iowa and its content may not be copied or emailed to multiple sites or posted to a listserv without the copyright holder's express written permission. However, users may print, download, or email articles for individual use. 